\title{
'Expanding before my very eyes!': spontaneous axillary artery branch bleeding resulting in a large, subpectoral haematoma
}

\author{
Eziefa Evelyn Obuseh
}

Emergency Department, Tallaght University Hospital, Dublin, Ireland

\section{Correspondence to Dr Eziefa Evelyn Obuseh; eziefa.obuseh@tuh.ie}

Accepted 28 August 2020
Check for updates

(c) BMJ Publishing Group Limited 2020. No commercial re-use. See rights and permissions. Published by BMJ.

To cite: Obuseh EE. BMJ Case Rep 2020;13:e238307. doi:10.1136/bcr-2020238307

\section{DESCRIPTION}

A 66-year-old woman presented to the emergency department with a mildly painful, right upper chest swelling, which had rapidly developed over the past few hours with no recalled trauma. She described it as 'expanding before her very eyes!'-this was echoed by the Triage Nurse who insisted that, within the half hour of Emergency Department arrival and initial assessments, it had increased in size.

On examination, the patient was alert, moderately pale and had a tachycardia of $108 \mathrm{bpm}$; her other vital signs were stable. Examination showed a large, firm, non-pulsatile swelling measuring approximately $20 \times 15 \times 3 \mathrm{~cm}$ to her right anterior chest wall above her right breast with no overlying discoloration or skin changes. She had full range of movement in her right shoulder and her respiratory examination was normal.

After securing large bore intravenous access, a CT scan of the thorax with contrast was promptly done and showed a $13.4 \times 9.5 \times 16.0 \mathrm{~cm}$ right anterior chest wall haematoma displacing her pectoralis major muscle anteriorly (see figure 1). It was supplied by an anterior branch of the right axillary artery, which was non-aneurysmal (see figure 2). Coil embolisation with two $3 \mathrm{~mm}$ helical coils was immediately done by interventional radiology, with good cessation of flow.

Despite prompt intervention, the patient's haemoglobin level dropped from 109 to $89 \mathrm{~g} / \mathrm{L}$ within a few hours of presentation and she required a blood transfusion. She was found to be coagulopathic secondary to alcoholic liver disease (prolonged prothrombin time (PT) $15.6 \mathrm{~s}$ and activated partial thromboplastin time (APTT) 40.4s) —this was the only identified predisposing factor for her spontaneous bleeding and she was given several doses of vitamin $\mathrm{K}$ during her admission. A repeat angiogram 4 days later showed an interval size reduction in her right chest wall haematoma to $12.8 \times 6.5 \times 15.4 \mathrm{~cm}$, and a subsequent liver biopsy showed steatohepatitis and fibrosis without cirrhosis.

She was discharged 20 days later with ongoing investigations to outrule other predisposing conditions to spontaneous bleeding.

Spontaneous arterial bleeding is unusual and as such requires a high index of suspicion and rapid intervention due to the significant blood loss which results. ${ }^{12}$ There are documented cases of spontaneous arterial bleeding in patients with Ehlers-Danlos syndrome, Marfan syndrome, with liver disease ${ }^{3}$ or chronic renal failure, ${ }^{4}$ on

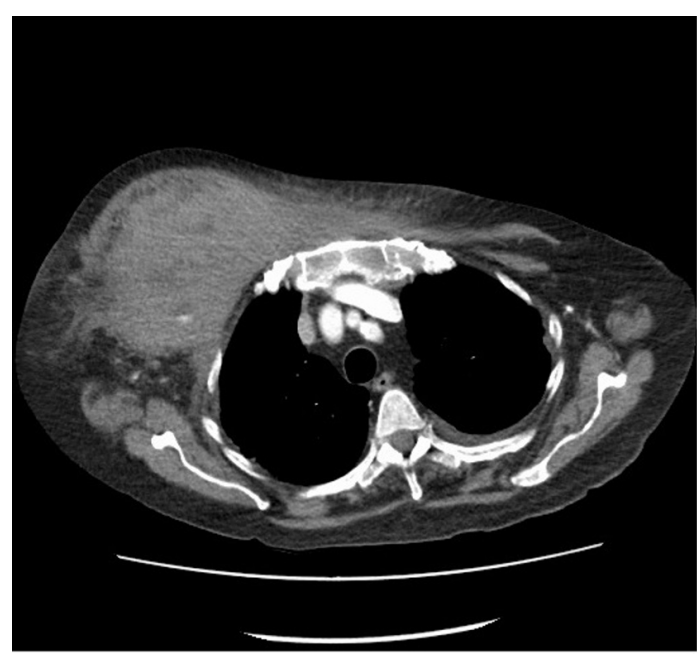

Figure 1 CT scan of the thorax (axial view) showing large right anterior chest wall haematoma.

immunosuppressive medication, ${ }^{5}$ etc, but spontaneous arterial bleeding especially in the absence of an aneurysm is generally rare. Endovascular approaches such as embolisation or stent grafting provide an alternative and/or additional treatment option to open vascular repair and will often be preferred if available, especially in a haemodynamically stable patient with atraumatic bleeding such as was the case in this patient. ${ }^{6}$ However, some arterial bleeding still require a wide variety of open

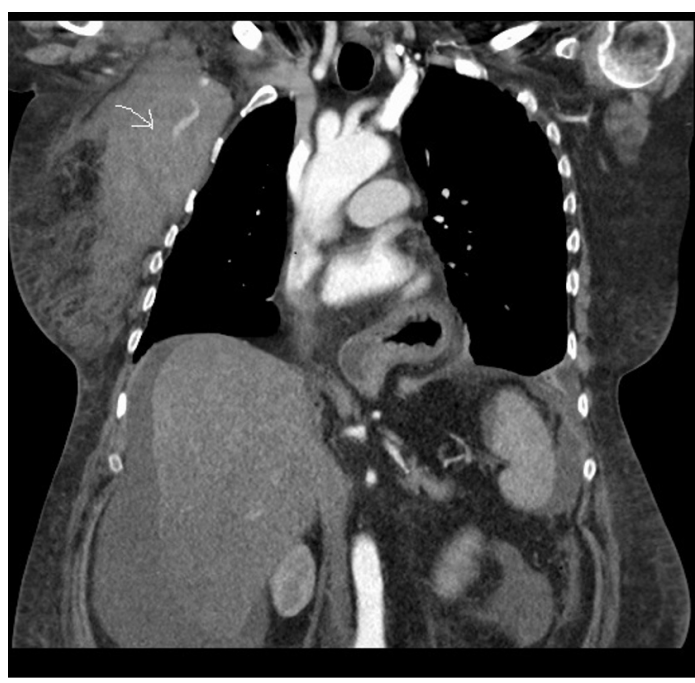

Figure 2 CT scan of the thorax (coronal view) showing haematoma and supplying arterial branch. 
exposures and procedures, particularly in unstable patients or in traumatic arterial injuries. ${ }^{7}$

\section{Learning points}

- Prompt access to CT imaging and interventional radiology (I.R.) facilities is instrumental to improving outcomes in cases of spontaneous arterial bleeding.

- A high index of suspicion and a sense of urgency is required when presented with such a case as the patient can rapidly progress to haemodynamic instability and may require surgical intervention.

- Intervention such as insertion of large bore intravenous access, cardio-respiratory monitoring, etc, should be instituted prior to transfer for CT scan and the vascular surgery team should be involved prior to proceeding to I.R., as the patient may need to go to theatre if embolisation is unsuccessful or if they become unstable.

Acknowledgements Dr Aileen McCabe, Emergency Medicine Consultant, Tallaght University Hospital, Dublin 24, Ireland.

Contributors EEO: patient consent, image retrieval, write-up and literature search.
Funding The authors have not declared a specific grant for this research from any funding agency in the public, commercial or not-for-profit sectors.

Competing interests None declared.

Patient consent for publication Obtained.

Provenance and peer review Not commissioned; externally peer reviewed.

\section{REFERENCES}

1 Dua A, Dua A, Jechow $S$, et al. Idiopathic spontaneous rupture of an intercostal artery. WMJ 2014;113:116-8.

2 Tombesi P, Di Vece F, Salviato E, et al. Spontaneous active bleeding in thoracoacromial artery diagnoses by contrast-enhanced ultrasound - a case report. Ultraschall Med 2012;33:E355-6.

3 Takamura M, Watanabe J, Sakamaki A, et al. Alcoholic liver disease complicated by deep bleeding into the muscles or retroperitoneum: report of three cases and a review of the literature. Intern Med 2014;53:1763-8.

4 Halak M, Kligman M, Loberman Z, et al. Spontaneous ruptured lumbar artery in a chronic renal failure patient. Eur J Vasc Endovasc Surg 2001;21:569-71.

5 Karaçağlar E, Akgün AN, Aytekin C, et al. Successful treatment of a rare complication in a heart transplant recipient: spontaneous axillary artery bleeding. Exp Clin Transplant 2019;17:421-4.

6 Trellopoulos G, Georgiadis GS, Aslanidou EA, et al. Endovascular management of peripheral arterial trauma in patients presenting in hemorrhagic shock. J Cardiovasc Surg 2012;53:495-506.

7 Waller CJ, Cogbill TH, Kallies KJ, et al. Contemporary management of subclavian and axillary artery injuries-A Western trauma association multicenter review. J Trauma Acute Care Surg 2017;83:1023-31.

Copyright 2020 BMJ Publishing Group. All rights reserved. For permission to reuse any of this content visit

https://www.bmj.com/company/products-services/rights-and-licensing/permissions/

BMJ Case Report Fellows may re-use this article for personal use and teaching without any further permission.

Become a Fellow of BMJ Case Reports today and you can:

- Submit as many cases as you like

- Enjoy fast sympathetic peer review and rapid publication of accepted articles

- Access all the published articles

- Re-use any of the published material for personal use and teaching without further permission

Customer Service

If you have any further queries about your subscription, please contact our customer services team on +44 (0) 2071111105 or via email at support@bmj.com.

Visit casereports.bmj.com for more articles like this and to become a Fellow 